\title{
Toward Inclusive Design Applications in Recreational Spaces for People with Disabilities in Egypt

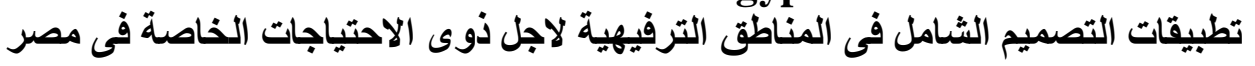

\author{
Menna Allah Mounir, Asmaa Nasr El-Dien, Lamis El-Gezawy \\ Mansoura University \\ Mennaalla60@gmail.com
}

\begin{abstract}
A disproportionate number of persons with disabilities live in developing countries, often marginalized and in extreme poverty. They face discrimination and barriers that restrict them from participating in society. About 10 to $12 \%$ of the total populations in Egypt are suffering from different types of disabilities. They face restrictions that prevent them from normal life, and then they lose their motivation for challenging their disabilities. Besides that, there are problems about accessing entertainment spaces to keep their positive energy.

Architects have their role to help people with disabilities to enjoy accessible recreational spaces although their disabilities. The aim of this research is to determine strategies for design entertainment spaces which is accessible, provide an integration in community with different abilities in a safe pleasing environment for all. This research will analyse examples of inclusion in recreational spaces in deferent countries, study universal design strategies that are common in these examples, then with making comparison between international strategies and the requirements which are included in the Egyptian Code, Conclusion can be achieved as a step toward accessible recreational spaces for people with disabilities.

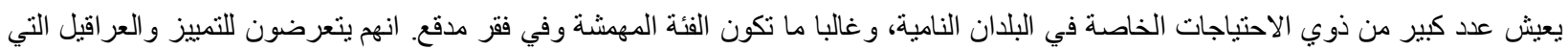

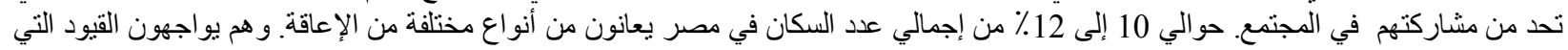

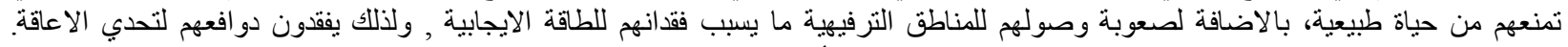

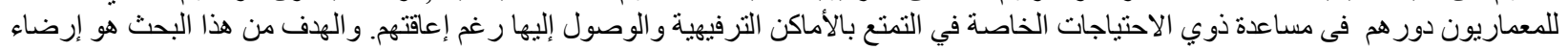

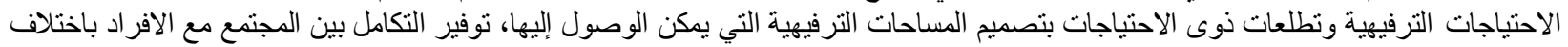

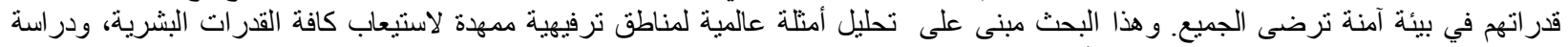

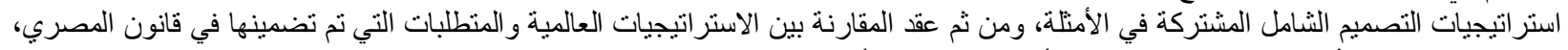

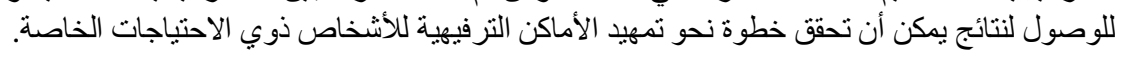

Keywords: PWDs (People with Disabilities), Recreational spaces, Accessibility and The Egyptian code requirements for construct

\section{INTRODUCTION:}

During the last decade, disability is increasingly considered as a human rights issue. Disability is also an important development issue with an increasing body of evidence proving that persons with disabilities experience worse socioeconomic outcomes and poverty than normal persons. Despite the magnitude of the issue, both awareness of and scientific information on disability issues are lacking.

There is no agreement on definitions and little internationally comparable information on the incidence, distribution and trends of disability. There are few documents providing a compilation and analysis of the ways countries have developed policies and responses to address the needs of people with disabilities. (Murray, 2013)

According to The World Bank that works for a world free of poverty, one billion people, or $15 \%$ of the world's population, experience some types of disability, and disability prevalence is higher for developing countries. (The World Bank, Apr 04, 2016) Globally, World Health Organization (WHO) understands disability as an interaction between health conditions and contextual factors, both personal and environmental. (World Health Organization, 2001).

According to WHO, Disability is the umbrella term for impairments, activity limitation and participation 
restrictions referring to the negative aspects of the interaction between an individual with a health conditions and that individual's contextual factors (environmental and personal factors). (World Health Organization, 2011).

Egypt is considered to possess the best statistics on persons with disabilities (PWDs) in the Arab World.

Despite this, most independent observers agree that the Government of Egypt grossly underestimates the numbers of its disabled population. In 1999, the Egyptian Ministry of Planning reported that there were approximately 1.1 million PWDs in Egypt, representing $1.7 \%$ of Egypt's population of 63 million at that time. In 2005, the World Bank conducted an extensive household survey in Egypt and found that PWDs numbered between 2.7 million to perhaps a high of 7 million, check Figure 1 . (Disability, 2015)

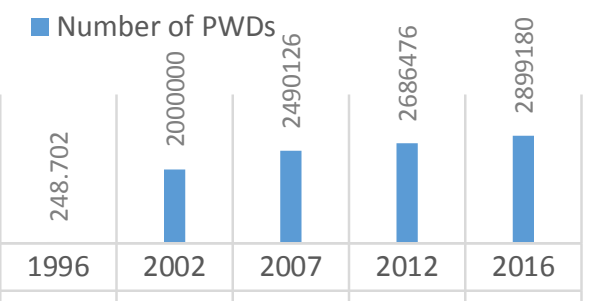

number of PWDs 248.7022000000249012626864762899180

\section{Figure 1: Shows the Exponential increase of PWDs}

Persons with disabilities in Egypt have long been marginalized because of many reasons as poverty, difficult in employment, social stigma and discrimination, lack of reliable information and opportunities in education. (Hakim \& Jaganjac, 2006) All these problems are related to the accessibility, then resections prevent them and lessen their positive energy, so research's focus is on accessibility of recreational spaces.

\section{METHODOLOGY:}

In an attempt to highlight the role of the architect in the inclusion between community and PWDs in recreational spaces, a number of cases studies will be analyzed. In order to ensure that relevant and appropriate projects cases are selected, specific criteria were used in the selection process as follows:

a. The projects, in particular, should be established by the government and is defined as a national park.

b. The projects should meet the minimum requirements of Americans with Disabilities Act (ADA).

Taking these criteria into consideration a systematic search through various National Parks, eight parks were found to match them sufficiently as mentioned in table 1 below.

Table 1: The Three Selected parks

\begin{tabular}{|c|c|}
\hline Park.1 & Pukeahu National War Memorial Park \\
\hline Park .2 & Bryce Canyon National Park \\
\hline Park .3 & Ocqueoc Falls Bicentennial Pathway \\
\hline
\end{tabular}

\subsubsection{Accessibility Strategies:}

\subsubsection{Accessible Entrance}

Figure 2 observes the map of Pukeahu National War Memorial Park and specify inclusion in landscape design to enter the park.

The access to park for is going South up Taranaki St. or North down Taranaki St. The bus routes that this accessible bus stop is located on are 10, 11, 18, 21 and 47. (Manatü Taonga, the Ministry for Culture and Heritage, 2015).

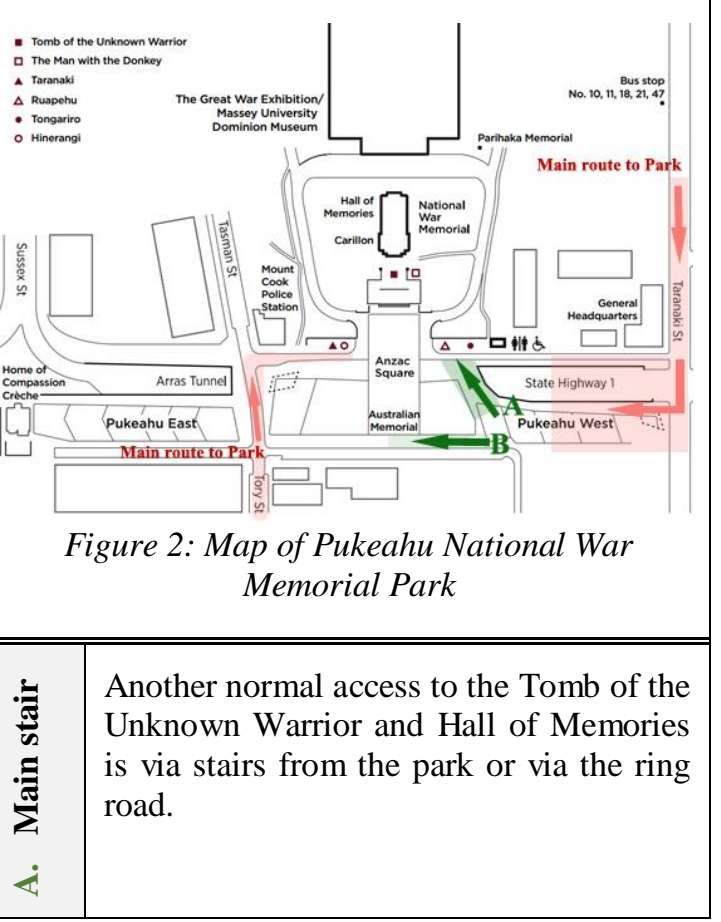



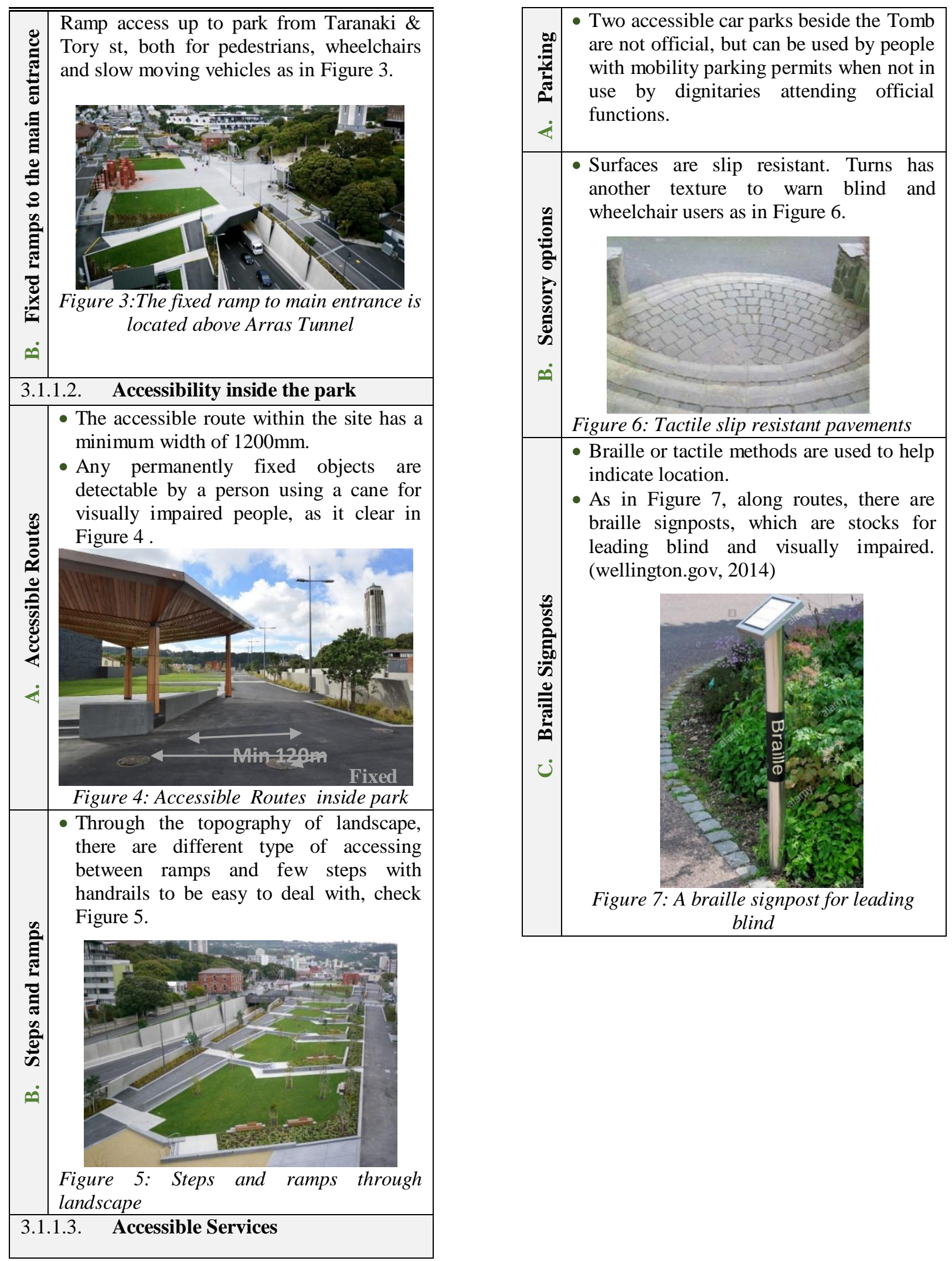


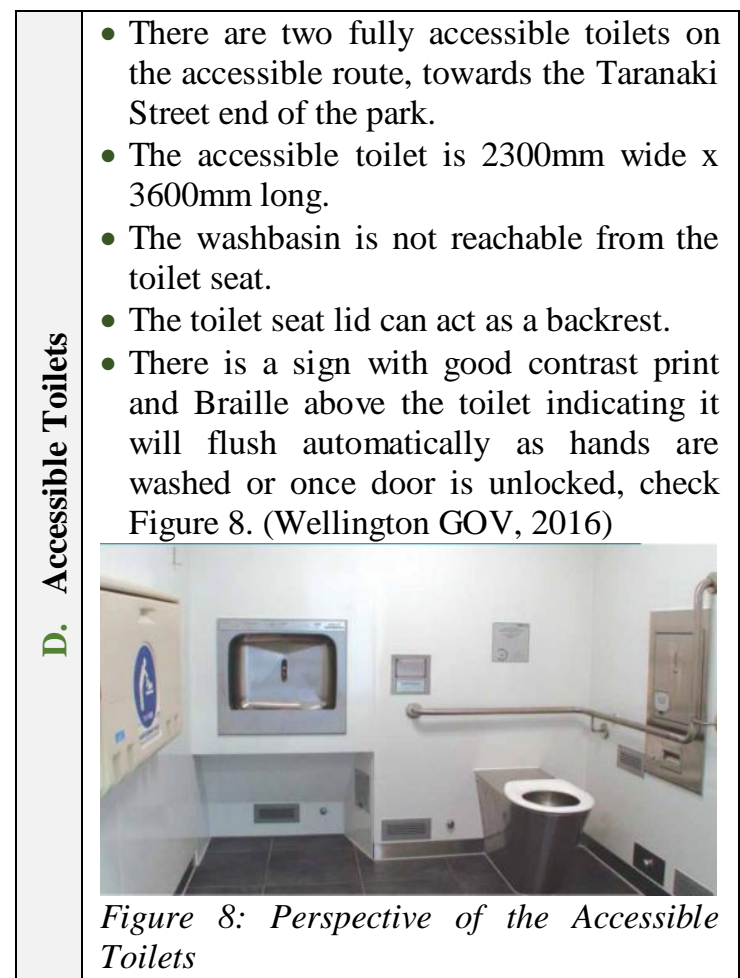

\subsection{Park (2):}

3.2.1. General Information: Bryce Canyon is established by The American National Park Service, located in southwestern Utah, United States. The park is characterized by an enormous array of oddly shaped "hoodoos," unique erosional formations whimsically arranged and tinted with a variety of subtle colors. (National Park, 2015).

3.2.2. The purpose of the park: According to the website of the park, there is no place like Bryce Canyon; there is the largest collection of hoodoos in the world. In this special land, there are many activities to do like (Camping- Horseback ridingPhotography).

\subsubsection{Accessibility Strategies:}

\subsubsection{Accessible Entrance}

One of the main goals of the national park service is to make all park in USA suitable for all people. That includes Bryce Canyon although it's hard landscape. it aims:

- Increasing the ability Bryce Canyon to serve visitors with disabilities.

- People with varying abilities and their families will be included in the ways that visitors access park experience parks.

\begin{tabular}{|c|c|}
\hline 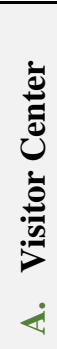 & $\begin{array}{l}\text { - Two moderately sloping ramps lead from } \\
\text { the parking lot to the Visitor Center. } \\
\text { - The building is equipped with a fully } \\
\text { accessible auditorium with a } 22 \text {-minute } \\
\text { captioned film. Restrooms have fully } \\
\text { accessible stalls }\end{array}$ \\
\hline 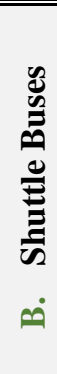 & $\begin{array}{l}\text { - Optional shuttles are fully accessible and } \\
\text { operated. Buses stop at the Visitor } \\
\text { Center, Bryce Canyon Lodge, North and } \\
\text { Sunset Campground, and Bryce, } \\
\text { Inspiration, Sunset, and Sunrise points. } \\
\text { Guided bus tours to the southern } \\
\text { viewpoints are also offered twice daily in } \\
\text { summer. (National Park Service Geologic } \\
\text { Resources Division, 2013) }\end{array}$ \\
\hline \multicolumn{2}{|c|}{$\begin{array}{l}\text { Figure } 9 \text { :The Upper part of the park's map } \\
\text { showing the access to entrance, visitor center } \\
\text { and Shuttle Buses boarding }\end{array}$} \\
\hline & 3.2. Accessibility inside the park \\
\hline
\end{tabular}




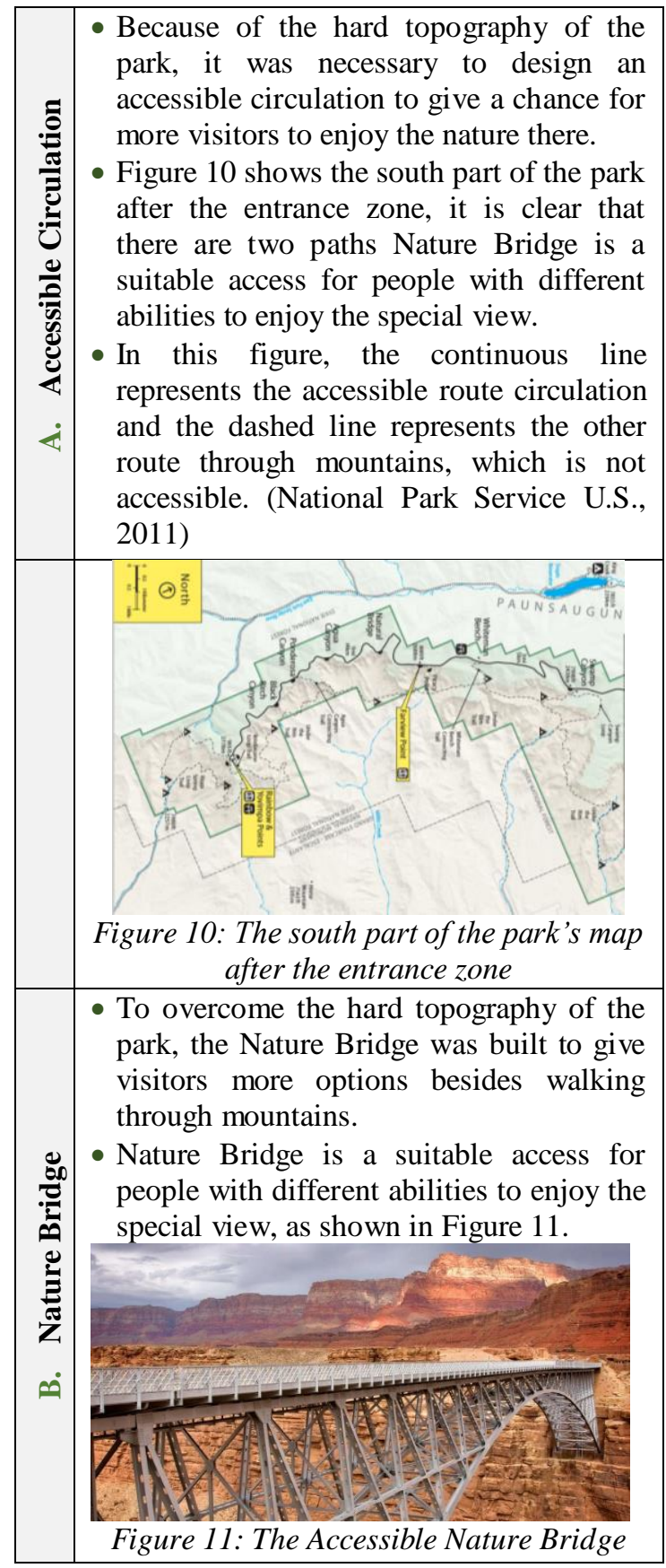

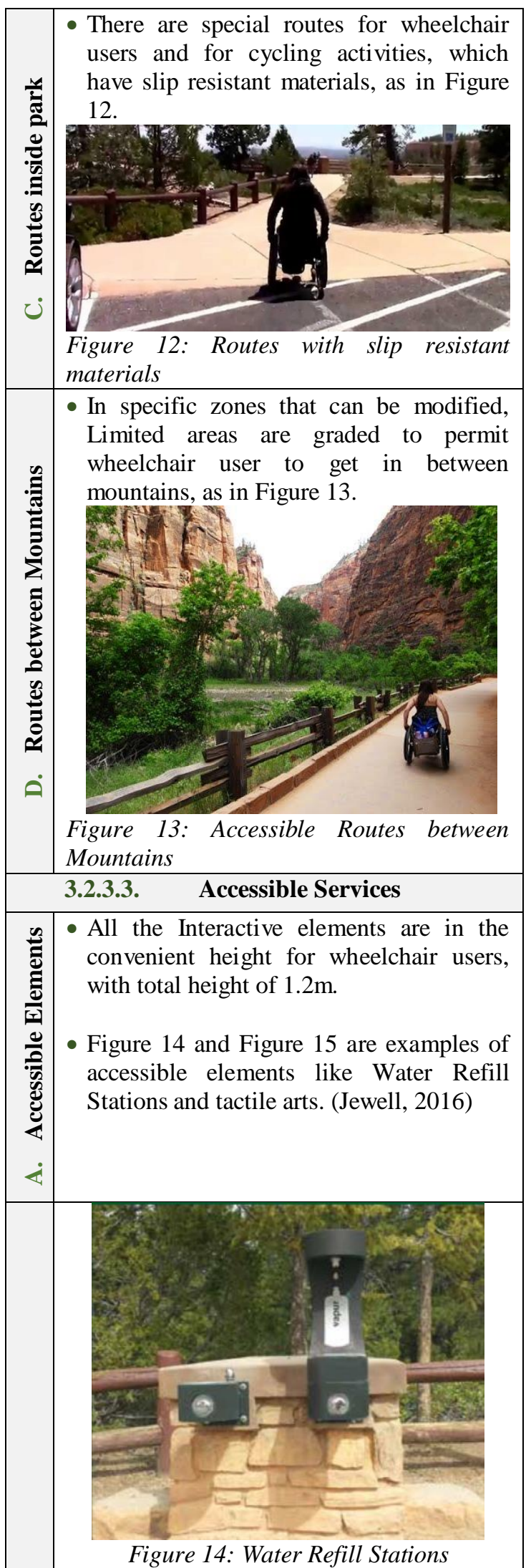




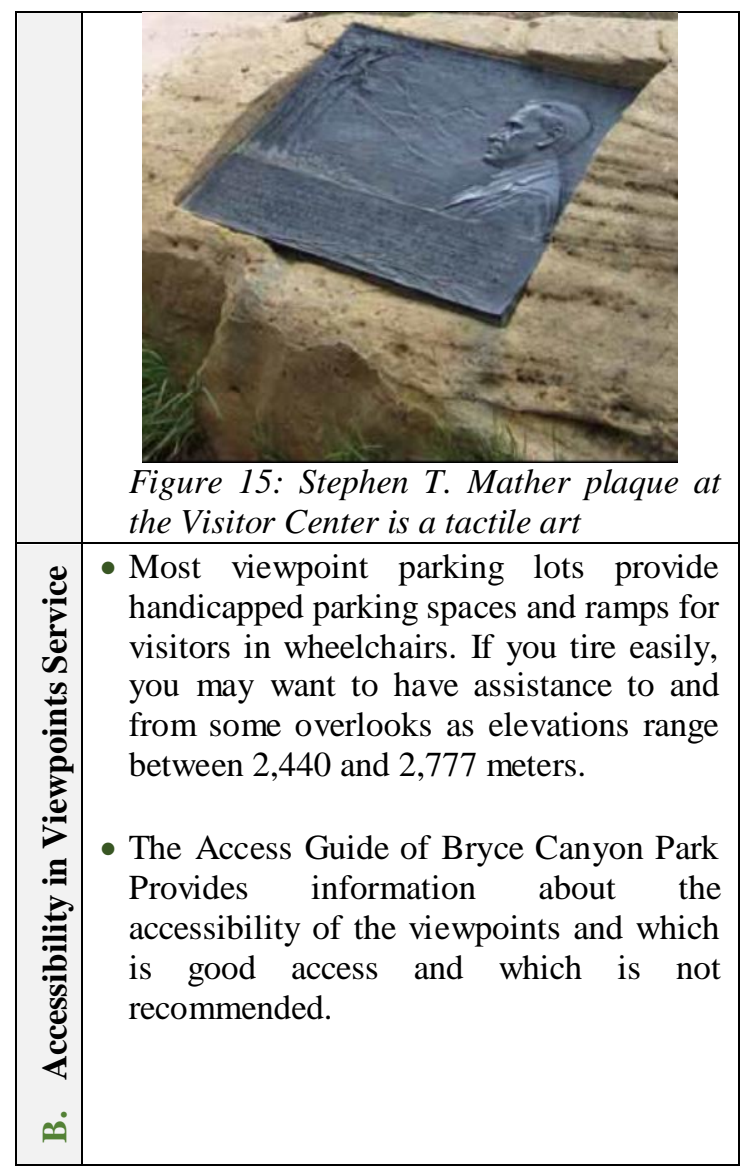

\subsection{Park (3):}

3.2.1. General Information: Ocqueoc Falls Bicentennial Pathway in Michigan, United States is established by Michigan Department of Natural Resources, contains one of the few waterfalls in the lower peninsula of Michigan. ((DNR) Michigan Department of Nature Recourses, 2014)

3.2.2. The purpose of the park: Visitors of all abilities can experience the first universally accessible waterfall.

\subsubsection{Accessibility Strategies:}

3.3.3.1. Accessible Entrance

- Access is possible by ramp with soft slob, paved trail connects from the parking. Figure 16 shows The Entrance ramp with 1: 8 slop which is less that the maximum standard slop (1: 12).

Figure 16: The Entrance ramp to access the waterfall

\subsubsection{Accessibility inside the park}

Routes in the Pathway match the requirements of ADA (Americans with Disabilities Act ):

- Minimum width of routes is $1.2 \mathrm{~m}$.

- The ground surface extends more than 305 beyond the inside face of handrails.

- The provided clearance is 760 wide above the ground surface beyond the railing.

- Figure 17 is one of the accessible sloping routes that matches the ADA requirements.

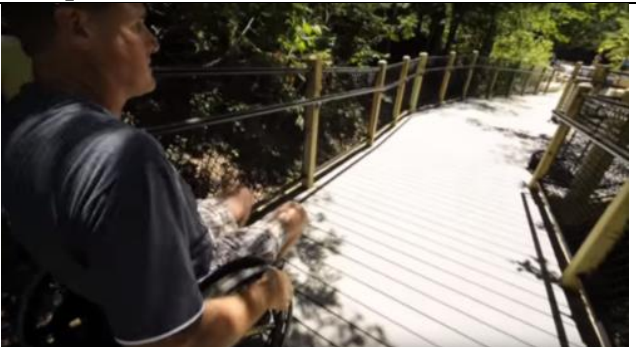

Figure 17: One of sloping route that leads to the waterfall

- As the pathway is sloping to the waterfalls, It has accessible steps of stone
that makes them slip resistant and have a short height of risers to help wheelchair user to interact safely with it.

- As shown in Figure 18 is an experience อุ of one of wheelchair user's visitor approve the process of passing steps. 


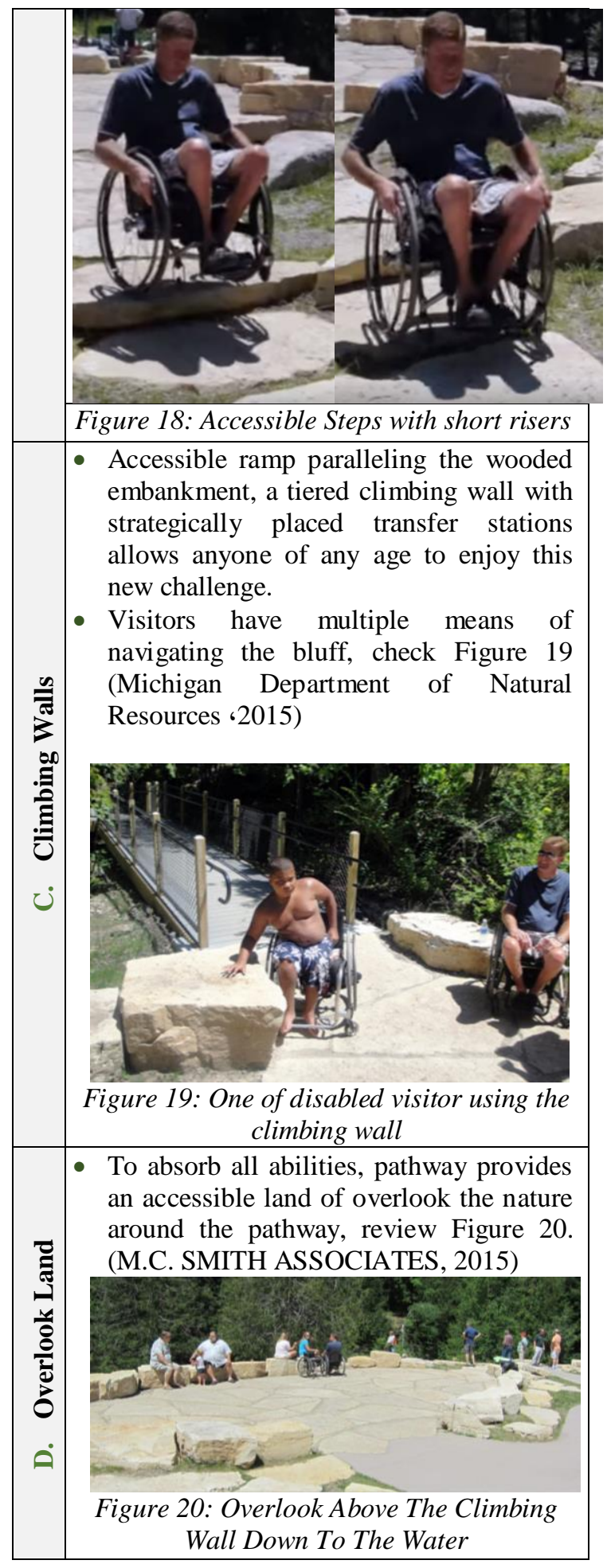

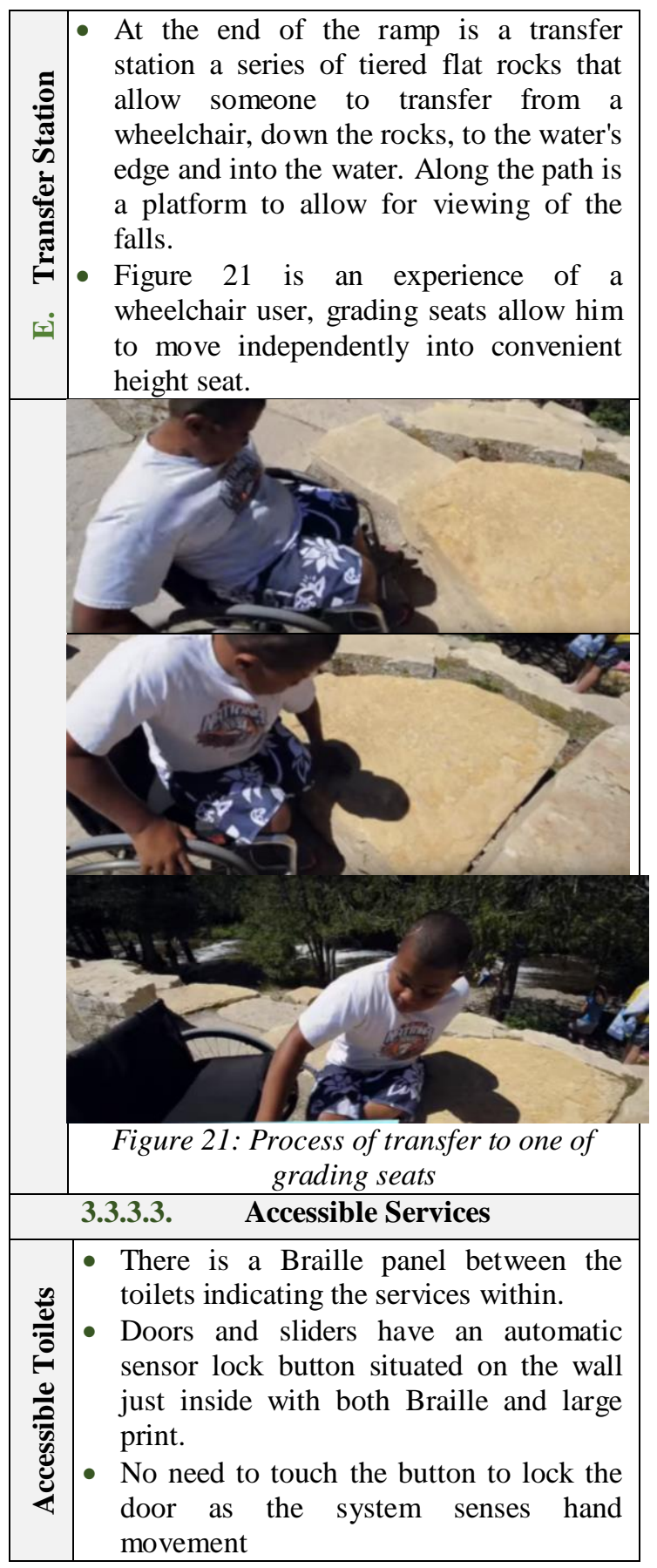


4. EGYPTIAN CODE FOR OUTDOOR SPACES AND BUILDINGS DESIGN FOR PWDS ANALYZING: (HOUSING AND BUILDING RESEARCH CENTER ، 2005)

\subsection{Entrances and gates:}

- Entrances and gates must be near the parking lot and bus stations.

- At least one entrance should has the same level of curb or provides accessible ramp.

- In case of Turnstiles, there should be hinged door beside it for PWDs.

- The minimum width of door is $1 \mathrm{~m}$.

\subsection{Routes:}

- The minimum width of the route is $1.5 \mathrm{~m}$ and the maximum slop is 1:20.

- The route floor should have a tough texture without barriers.

\subsection{Ramps:}

- The maximum slop of any ramp is $1: 12$ with minimum width $1.5 \mathrm{~m}$.

- Handrails should be provided with $0.80 \mathrm{~m}$ height and extended $0.30 \mathrm{~m}$ before and after the ramp.

\subsection{Floors:}

- The maximum slop of any ramp is $1: 12$ with minimum width $1.5 \mathrm{~m}$.

- In case of area of sand or grass, paved route should be provided to enable PWDs.

\subsection{Furniture:}

- Furniture should have different texture to be distinguished by visual impaired people.

- It should be far from routes at least 100:200m.

4.6. Toilets:

- At least one accessible toilet should be provided.

(Housing and Building Research Center ، 2005)

\section{DISCUSSION}

From the analyzing of the case studies concerning the main requirements that included in the Egyptian code, it will be a comparison of 3 axis (Entrances, routes inside the park and accessible service), it is clear in Table 2

Table 2: Comparison between case studies \& Egyptian code

\begin{tabular}{|c|c|c|c|c|c|}
\hline & $\begin{array}{c}\text { Pukeahu } \\
\text { National War } \\
\text { Memorial Park } \\
\end{array}$ & $\begin{array}{l}\text { Bryce Canyon } \\
\text { National Park }\end{array}$ & $\begin{array}{c}\text { Ocqueoc Falls } \\
\text { Bicentennial } \\
\text { Pathway }\end{array}$ & Egyptian code \\
\hline \multirow{3}{*}{ 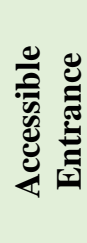 } & Stairs & $\begin{array}{c}\text { One stair } \\
\text { (secondary) }\end{array}$ & No Stairs & No Stairs & $\begin{array}{c}\text { Stairs } \\
\text { (Main Entrance) }\end{array}$ \\
\hline & Ramps & $\begin{array}{l}\text { The main } \\
\text { Entrance }\end{array}$ & $\begin{array}{l}\text { The main } \\
\text { Entrance }\end{array}$ & $\begin{array}{l}\text { The main } \\
\text { Entrance }\end{array}$ & Secondary Entrance \\
\hline & $\begin{array}{c}\text { Bus } \\
\text { stations }\end{array}$ & $\begin{array}{l}\text { Station provides } \\
\text { accessible buses }\end{array}$ & $\begin{array}{l}\text { Station provides } \\
\text { accessible buses }\end{array}$ & - & $\begin{array}{l}\text { accessible buses not } \\
\text { valid }\end{array}$ \\
\hline \multirow{3}{*}{ 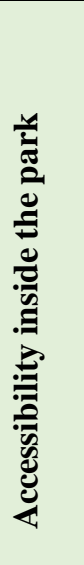 } & $\begin{array}{l}\text { Accessible } \\
\text { Routes }\end{array}$ & $\begin{array}{c}\text { Minimum width: } \\
1.2 \mathrm{~m} \text {, any fixed } \\
\text { objects are } \\
\text { detectable }\end{array}$ & $\begin{array}{l}\text { special routes for } \\
\text { PWDs with slip } \\
\text { resistant } \\
\text { materials }\end{array}$ & $\begin{array}{c}\text { Minimum } \\
\text { width: } 1.2 \mathrm{~m} \text {, } \\
\text { handrail } \\
\text { extends } 0.30 \mathrm{~m} \\
\text { before and after } \\
\end{array}$ & $\begin{array}{c}\text { The min width } 1.5 \mathrm{~m} \\
\text { \&max. Slop: } 1: 20 \text {. } \\
\text { The route has tough } \\
\text { texture without } \\
\text { barriers. }\end{array}$ \\
\hline & $\begin{array}{l}\text { Accessible } \\
\text { Steps }\end{array}$ & $\begin{array}{c}\text { Stairs are not } \\
\text { accessible } \\
\text { because there are } \\
\text { ramps }\end{array}$ & $\begin{array}{l}\text { Topography is } \\
\text { hard, so bridge is } \\
\text { provided }\end{array}$ & $\begin{array}{l}\text { Short height of } \\
\text { risers helps } \\
\text { PWDs to } \\
\text { interact safely. }\end{array}$ & - \\
\hline & $\begin{array}{c}\text { Transfer } \\
\text { Station }\end{array}$ & - & - & $\begin{array}{c}\text { allows moving } \\
\text { independently } \\
\text { From } \\
\text { wheelchair } \\
\text { down the seats. }\end{array}$ & - \\
\hline
\end{tabular}




\begin{tabular}{|c|c|c|c|c|c|}
\hline & $\begin{array}{c}\text { Pukeahu } \\
\text { National War } \\
\text { Memorial Park }\end{array}$ & $\begin{array}{l}\text { Bryce Canyon } \\
\text { National Park }\end{array}$ & $\begin{array}{c}\text { Ocqueoc Falls } \\
\text { Bicentennial } \\
\text { Pathway } \\
\end{array}$ & Egyptian code \\
\hline \multirow{4}{*}{ 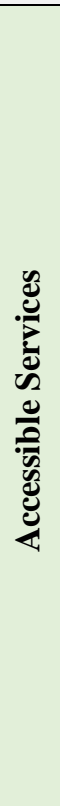 } & $\begin{array}{l}\text { Accessible } \\
\text { Toilets }\end{array}$ & $\begin{array}{l}\text { Two accessible } \\
\text { separated toilets } \\
\text { Accessible Toilets } \\
\text { include sensory } \\
\text { options for all } \\
\text { disabilities }\end{array}$ & $\begin{array}{c}\text { accessible toilets } \\
\text { in all view zones } \\
\text { Accessible } \\
\text { Toilets include } \\
\text { sensory options } \\
\text { for all disabilities }\end{array}$ & $\begin{array}{c}\text { Two accessible } \\
\text { separated toilets } \\
\text { Accessible } \\
\text { Toilets include } \\
\text { sensory options } \\
\text { for all } \\
\text { disabilities }\end{array}$ & $\begin{array}{l}\text { At least one toilet } \\
\text { The requirements are } \\
\text { about dimensions } \\
\text { only, no sensory } \\
\text { option is mentioned } \\
\text { in the code }\end{array}$ \\
\hline & $\begin{array}{l}\text { Accessible } \\
\text { Elements }\end{array}$ & $\begin{array}{c}\text { Furniture } \\
\text { accessible with } \\
\text { wheelchair user }\end{array}$ & $\begin{array}{c}\text { Elements with } \\
\text { convenient } \\
\text { height for } \\
\text { PWDs, }(1.2 \mathrm{~m}) .\end{array}$ & $\begin{array}{l}\text { Flat rocks that } \\
\text { allow someone } \\
\text { to transfer from } \\
\text { a wheelchair }\end{array}$ & $\begin{array}{l}\text { Furniture has } \\
\text { different texture to be } \\
\text { distinguished. } \\
\text { be far from routes at } \\
\text { least } 100: 200 \mathrm{~m}\end{array}$ \\
\hline & $\begin{array}{l}\text { Sensory } \\
\text { options }\end{array}$ & $\begin{array}{l}\text { Braille Signposts } \\
\text { Braille or tactile } \\
\text { methods are used } \\
\text { to indicate } \\
\text { location }\end{array}$ & $\begin{array}{l}\text { Tactile Arts \& } \\
\text { elements with } \\
\text { rough texture }\end{array}$ & - & $\begin{array}{l}\text { Sensory options are } \\
\text { not valid }\end{array}$ \\
\hline & Parking & $\begin{array}{l}\text { Two accessible } \\
\text { places in the } \\
\text { parking lot }\end{array}$ & $\begin{array}{l}\text { All parking lots } \\
\text { are accessible }\end{array}$ & - & $\begin{array}{l}\text { Necessary to provide } \\
\text { accessible parking } \\
\text { near entrances }\end{array}$ \\
\hline
\end{tabular}

\section{CONCLUSION}

From the above discussion, it is found that the Egyptian code meet the minimum requirements in general, but there are other strategies didn't mentioned there are important and there are main differences in design priorities, that reflects on the recommendations of the research from comparison results:

\section{A. Accessible Entrances:}

- Ramps are not the main Entrance, so one ramp may not absorb the convenient number accessing parks, especially at festivals.

- The necessary of providing accessible public transportation is not mentioned in the code.

\section{B. Accessibility inside the park:}

- Accessible routes standards are matching these are designed in case studies.

- Accessible Steps: there is no recommendation about the stairs or steps to be accessible.

- Transfer Station strategy is not mentioned in the code.

\section{Accessible Service:}

- Number of toilets in code is less than that in case studies.

- Furniture feathers are the same in case studies.

- Sensory options are not mentioned in the Egyptian code.

- Accessible Parking standards are matching these are designed in case studies

The results enable upgrading Egyptian code for outdoor spaces and buildings design for PWDs. In addition to that, research recommends to create system of supervision for Egyptian National Parks to insure the design quality. 


\section{REFERENCES}

(DNR) Michigan Department of Nature Recourses, 2014. Welcoming waters of northern Michigan's Ocqueoc Falls have universal appeal. [Online]

Available at:

http://www.michigan.gov/dnr/0,4570,7-153-

10366 41825-283510--,00.html

[Accessed 179 2016].

Disability, N. A. o., 2015. improving women with disability in Egypt, s.l.: s.n.

Hakim, G. \& Jaganjac, N., 2006. A note on disability issues in the Middle East and North Africa, s.l.: The World Bank.

Housing and Building Research Center, 2005. Egyptian code for outdoor spaces and buildings design for PWDs. 1st ed. Cairo: The Standing Committee of Egyptian Code.

Jewell, S., 2016. Map, Shuttle \& Hiking Guide. The hoodoo (Official newspaper of Bryce Canyon National Park), pp. 2-7.

M.C. SMITH ASSOCIATES, 2015. PARK AND RECREATION PLANNING AND DESIGN, s.l.: M.C. SMITH ASSOCIATES.

Manatū Taonga, the Ministry for Culture and Heritage, 2015. Pukeahu National War Memorial Park. [Online]

Available at: http://www.mch.govt.nz/pukeahunational-war-memorial-park

[Accessed 149 2016].

Michigan Department of Natural Resources, 2015. Accessible trail opens Michigan's Ocqueoc Falls to all. [Online]

Available at:

file:///E:/Architecture/Master/Data\%20of\%20ma ster/to\%20read/analysis/Ocqueoc\%20Falls/Acce ssible\%20trail\%20opens\%20Michigan\%E2\%80 $\% 99$ s $\% 20$ Ocqueoc\%20Falls\%20to\%20all.html [Accessed 1111 2016].

Murray, C. J. e. a., 2013. "Disability-adjusted life years (DALYs) for 291 diseases and injuries in 21 regions, 1990-2010: a systematic analysis for the Global Burden of Disease Study 2010.. s.1.:s.n.

National Park Service Geologic Resources Division, 2013. Bryce Canyon National Park
GRI Ancillary Map Information Documen, Canyon : brca_geology.

National Park Service U.S., 2011. ACCESS GUIDE Bryce Canyon National Park, Bryce Canyon : Department of the Interior Bryce Canyon National ParkAccess .

National Park, 2015. Hoodoos and forest mixed together. [Online]

Available at:

https://www.nps.gov/brca/index.htm [Accessed 169 2016].

The World Bank, Apr 04, 2016. Disability Overview - World Bank- Overview, s.1.: http://www.worldbank.org/en/topic/disability/ov erview.

Wellington GOV, 2016. Risk Assessment Management (RAM), Wellington: Great War Exhibition .

wellington.gov, 2014. ACCESSIBLE SERVICES AND FACILITIES - WELLINGTON CITY, wellington: Ministry of culture.

World Health Organization, 2001. The International Classification of Functioning, Geneva: Disability and Health.

World Health Organization, 2011. World Report on Disability, USA: World Health Organization (WHO). 
Menna Allah Mounir, Asmaa Nasr El-Dien, Lamis El-Gezawy "Toward Inclusive Design Applicati...” 